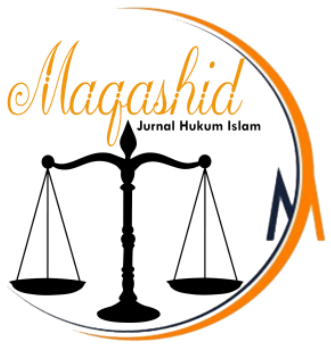

Al-Ahwal Al-Syakhsiyah, IAI Al-Qolam

Maqashid (2020) Vol.3. No.l: 96-114

http://ejournal.alqolam.ac.id/index.php/maqashid

p-ISSN: 2613-9758

e-ISSN : 2685-4619

(c) Maqashid 2020

\title{
UNSUR KEMASLAHATAN PADA HIBAH SUAMI - ISTRI
}

\author{
Muhammad Zainuddin Sunarto \\ Universitas Nurul Jadid Paiton Probolinggo \\ Email: zain2406@gmail.com
}

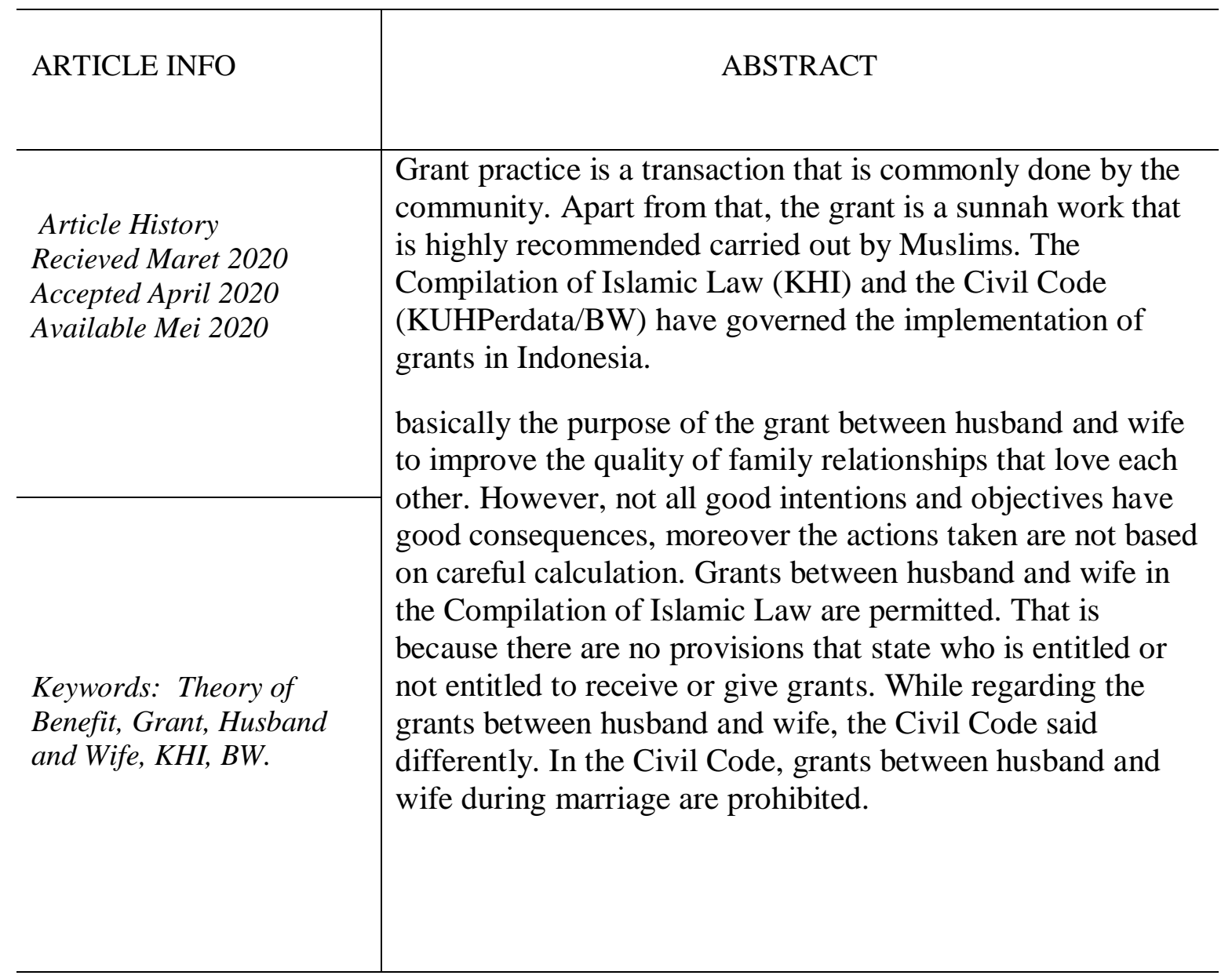




\section{Pendahuluan}

Hibah merupakan transaksi yang sangat lumrah terjadi di masyarakat. Selain dari itu, hibah merupakan sunnah yang sangat dianjurkan dilaksanakan oleh umat Islam. Banyak orang memahami, bahwa hibah sebatas pemberian, tidak memahami faedah yang dimiliki oleh disyariatkan hibah. Sehingga butuh aturan yang pasti, yang mengatur tentang pelaksanaan hibah di Indonesia. Tujuan dengan adanya aturan tersebut, untuk memberikan kepastian kepada masyarakat pada pelaksanaan hibah, baik sisi pengertia, tujuan, tatacara, akibat hukum, akibat hukum, serta larangan-larangan yang harus dijauhkan pada pelaksanaan hibah tersebut. Dalam konteks tersebut, Indonesia sudah memiliki aturan tentang Hibah dalam Kompilasi Hukum Islam (KHI) dan Kitab Undangundang Hukum Perdata (KUHP).

Hibah merupakan salah satu cara dalam Islam untuk memberikan pelajaran tentang tolong menolong dalam menanamkan kebajikan sesama manusia yang bernilai sangat positif. Ulama fiqih sepakat bahwa hibah dihukumi sunah, sesuai firman Allah SWT. dalam surah Al-Nisa' ayat 4 yaitu: ${ }^{1}$

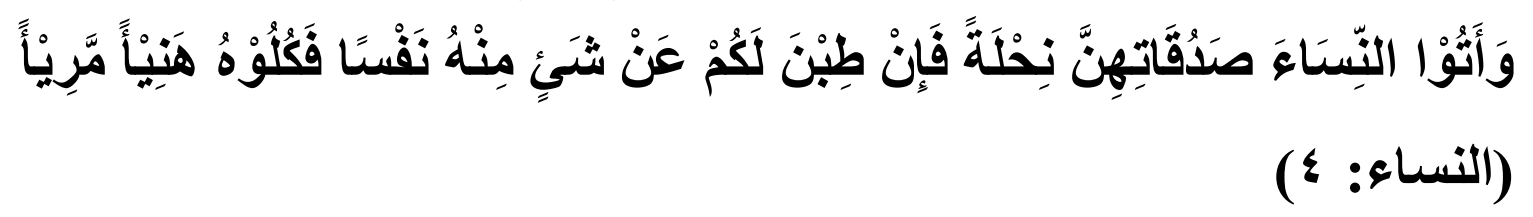

"Berikanlah maskawin (mahar) kepada wanita (yang kamu nikahi) sebagai pemberian dengan penuh kerelaan. Kemudian jika mereka menyerahkan kepada kamu sebagian dari maskawin itu dengan senang hati, Maka makanlah (ambillah) pemberian itu (sebagai makanan) yang sedap lagi baik akibatnya." (An Nisa': 4)

Maskawin yang dalam akad nikah adalah menjadi hak istri dan berada penuh pada kekuasannya. Oleh sebab itu, istri berhak membelanjakan, menghibahkan, mensedekahkan, dan sebagainya dengan tiada perlu meminta izin kepada walinya atau suaminya. Begitu pula harta benda istri yang lain tetap menjadi hak miliknya dan tidak ada hak suami untuk menghalanginya, kecuali kalau istri itu safih (pemboros, tiada pandai berbelanja), maka istri itu boleh dilarang mentasharrufkan harta bendanya. Pendeknya kepemilikan istri pada harta bawaannya tetap berlaku dan tidak berkurang sedikit pun karena terjadinya perkawinan. ${ }^{2}$

\footnotetext{
${ }^{1}$ Abdul Aziz Dahlan, Ensiklopedi Hukum Islam, Jilid II, (Jakarta: PT. Ichtiar Baru Van Hoeve, 1996), 540.

${ }^{2}$ Mahmud Yunus, Hukum Perkawinan Dalam Islam (Jakarta: PT. Hidakarya Agung, 1996), 108.
} 
Menurut istilah, hibah merupkan akad yang dilaksanakan oleh kedua belah pihak untuk pemindahan hak milik kepada orang lain pada waktu pemberi hibah masih hidup. ${ }^{3}$ Hibah juga merupakan suatu pemberian yang tidak ada kaitannya dengan kehidupan keagamaan. Tetapi yang menjadi pokok pengertian dari hibah ini selain unsur keikhlasan dan kesukarelaan seseorang dalam memberikan sesuatu kepada orang lain adalah pemindahan hak dan hak miliknya. Di dalam Hukum Islam yang dimaksud dengan hibah adalah pemindahan hak dan hak milik dari sejumlah kekayaan. ${ }^{4}$

Maksud dan tujuan hibah itu sendiri adalah agar antara penghibah dan penerima hibah itu timbul rasa saling mencintai dan menyayangi. Akan tetapi tidak semua maksud dan tujuan yang baik itu menimbulkan akibat yang baik pula, apalagi tindakan yang dilakukan itu tanpa di dasari perhitungan yang matang.

Ikatan perkawinan memiliki akibat hukum dalam harta perkawinan, yaitu semua harta yang diperoleh selama perkawinan. Harta perkawinan ini menjadi harta bersama milik suami dan istri, sekalipun hanya suami yang bekerja. Di dalam pasal 1 ayat (f) Kompilasi Hukum Islam (KHI) disebutkan bahwa harta kekayaan dalam perkawinan atau syirkah adalah harta yang diperoleh baik sendiri-sendiri atau bersama-sama suamiistri selama dalam ikatan perkawinan berlangsung dan selanjutnya disebut harta bersama, tanpa mempersoalkan terdaftar atas nama siapapun ${ }^{5}$. Dengan demikian ada tiga macam harta dalam perkawinan, yaitu:

1. Harta pribadi suami atau harta bawaan suami;

2. Harta pribadi istri atau harta bawaan istri;

3. Harta perkawinan atau harta bersama, milik suami dan istri. ${ }^{6}$

Hibah dalam Fiqh memiliki tujuan untuk meningkatkan interaksi sosial yang lebih baik dan mendapatkan kemanfaatan hubungan antar manusia. Umat Islam diharapkan selalui memiliki rasa kedamaian dalam kehidupan bersama, hal ini sesuai dengan penamaan sesuai dengan maksud adanya agama Islam, yakni penebar kedamaian, memiliki rasa kasih sayang, dan saling memberikan bantuan dalam menyelesaikan setiap

\footnotetext{
${ }^{3}$ Dirjen Pembinaan Kelembagaan Agama Islam, Ilmu Fiqh, (Jakarta: Kementerian Agama RI, 1984), $207-$ 208.

${ }^{4}$ Abdul Djamali, Hukum Islam Berdasarkan Ketentuan Kurikulum Konsorsium Ilmu Hukum, (Bandung: Mandar Maju, 2002), 180.

${ }^{5}$ Pasal 1 Ayat (f) Intruksi Presiden No. 1 tahun 1991 tentang Kompilasi Hukum Islam

${ }^{6}$ Afdol, Penerapan Hukum Waris Islam secara Adil, (Surabaya: Airlangga University Press, 2013), 91-92.
} 
permasalahan. Untuk terciptanya hal tersebut, salah satu jalan yang dianjurkan oleh Islam adalah hibah. ${ }^{7}$ Dalam hal ini Rasulullah SAW. bersabda:

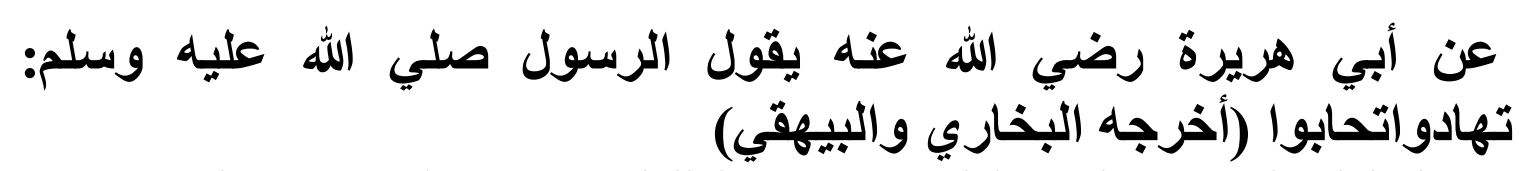

Dari Abu Hurairah r.a. Rasululloh saw. Bersabda:"saling memberilah kamu, niscaya kamu sekalian kasih mengasihi". (HR. Bukhori \& Baihaqy).

Sesuai dengan pengertian Hibah diatas, yang merupakan pemberian dengan secara cuma-Cuma serta tanpa adanya imbalan dari penerima hibah, dan dilaksanakan saat pemberi hibah masih hidup. Timbul sebuah permasalahan, bagaimana hibah yang dilaksanakan oleh suami istri, apakah diperbolehkan atau tidak diperbolehkan. Serta bagimana pemecahan masalah tersebut dari sisi kemaslahatan.

Permasalahan Hibah dibahas pada Pasal 1678 Kitab Undang-undang Hukum Perdata (KHUPer) disebutkan

Penghibahan antara suami istri selama perkawinan mereka masih berlangsung, dilarang. Tetapi ketentuan ini tidak berlaku terhadap hadiah atau pemberian berupa barang bergerak yang berwujud, yang harganya tidak mahal kalau dibandingkan dengan besarnya kekayaan penghibah

Dengan adanya larangan hibah antara suami-istri, pada Pasal 1678 KUH Perdata, timbul permasalahan. Bagaimana hibah antara suami-istri yang ada dalam KHI, apakah hal tersebut diperbolehkan. Sehingga dengan melihat aturan hibah yang ada dalam KUH Perdata maupun Kompilasi Hukum Islam maka nantinya akan dapat terlihat mana yang sesuai dengan teori kemaslahatan.

Pasal 86 dan 87 Kompilasi Hukum Islam (KHI) disebutkan tentang harta suami dan istri dalam perkawinan, serta korelasinya dengan Hibah.

Pasal 86

1) Pada dasarnya tidak ada percampuran antara harta suami dan harta istri karena perkawinan.

2) Harta istri tetap menjadi hak istri dan dikuasi penuh olehnya, demikian juga harta suami tetap

3) menjadi hak suami dan dikuasi penuh olehnya.

\footnotetext{
${ }^{7}$ Abdul Aziz Dahlan, Ensiklopedi Hukum Islam, Jilid 2, 540.
} 
Pasal 87

1) Harta bawaan masing-masing suami dan istri dan harta yang diperoleh masing-masing sebagai hasiah atau warisan adalah dibawah penguasaan masing-masing, sepanjang para pihak tidak menentukan lain dalam perjanjian perkawinan.

2) Suami dan istri mempunyai hak sepenuhnya untuk melakukan perbuatan hukum atas harta masing-masing berupa hibah, hadiah, sodaqah atau lainnya.

Permasalahn modern yang selalu timbul perlu dicarikan pemecahannya, yang bisa mengakomodir kebutuhan masyarakat, dalam Islam dikenal teori kemaslahatan. Kemaslahatan merupakan suatu teori yang lebih mementingkan kemaslahatan atau kemanfaatan manusia daripada mempersoalkan masalah-masalah yang terdapat dalam peraturan atau undang-undang. Karena terkadang antara teori kemaslahatan dengan teks yang ada dalam undang-undang itu tidak sejalan. Teori kemaslahatan dalam prakteknya adalah dar'ul mafasid (menolak kerusakan), jalb al-mashalih (mencari kemaslahatan), serta raf'ul haraj (menghilangkan kesulitan).

\section{Teori kemasalahatan pada prakteknya}

Teori kemaslahatan merupakan sebuah teori yang berasal dari teori Hukum Islam yang orientasinya lebih menekankan kepada unsur kemaslahatan atau kemanfaatan manusia itu sendiri daripada mempersoalkan masalah-masalah yang bersifat normatif saja. Teori ini tidak hanya melihat isi teks hukum (isi ayat al-Qur'an ataupun Hadits) maupun undang-undang yang berlaku pada sebuah wilayah, melainkan teori ini lebih ingin mencapai pada prinsip atau tujuan yang dikehendaki oleh syari' (Allah), hal tersebut tercantum pada nash atau teks hukum tersebut. Sehingga kalau dicermati sesungguhnya teori kemaslahatan ini justru ingin mengembangkan atau menerapkan isi dari tujuan syariah tersebut yang terdapat dalam teks hukum tersebut. Imam Najm AlDin al Thufy berpendapat, bahwasanya maslahat itu harus lebih dikedepankan daripada 
nash dalam hal muamalah (hubungan antara manusia dengan manusia yang lain, seperti hibah). Alasannya adalah sebagaimana yang terdapat dalam kitab Ushul Fiqh al-Islamy ${ }^{8}$ :
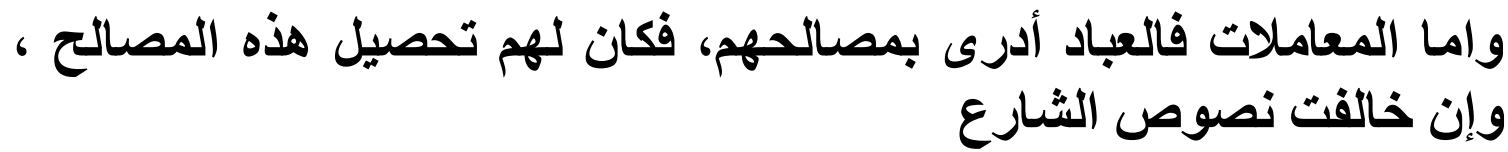

" pada bidang muamalat, para manusia akan lebih mengerti pada unsur kemaslahatan itu sendiri, oleh karena itu mereka sendiri berhak menentukannya sendiri, sekalipun bertentangan dengan Syari'at".

Teori Maslahat telah disampaikan oleh beberapa pakar hukum walaupun terdapat sedikit perbedaan, tetapi keseluruhannya mengarah kepada kemaslahatan manusia. Di antaranya adalah: Imam Najm al-Din al-Thufy dengan kitabnya "Al-Ta'yin fi Syarh al Arba'in, Imam Syatibi dengan kitabnya "Al-Muwafaqat", Imam Al-Ghazali dengan kitabnya "Al-Mustasyfa", dan lainnya.

Maslahat dipahami sebagai "setiap perbutan yang mengarah kebaikan manusia". Pada artinya yang berlaku adalah setiap segala hal yang bermanfaat bagi manusia, baik dalam arti menarik keuntungan atau menghasilkan kemudahan, atau dalam arti menolak kemadharatan atau kerusakan. Jadi secara etimologis, dapat simpulkan bahwa setiap yang mengandung manfaat patut disebut maslahat. ${ }^{9}$ Sedangkan dalam mengartikan maslahat secara terminologi terdapat perbedaan rumusan dikalangan ulama yang kalau dianalisa ternyata hakikatnya adalah sama.

Imam Ghazali dalam penjelasannya, bahwa maslahat itu berarti sesuatu yang mendatangkan manfaah (keuntungan) dan menjauhkan madharat (kerusakan), namun

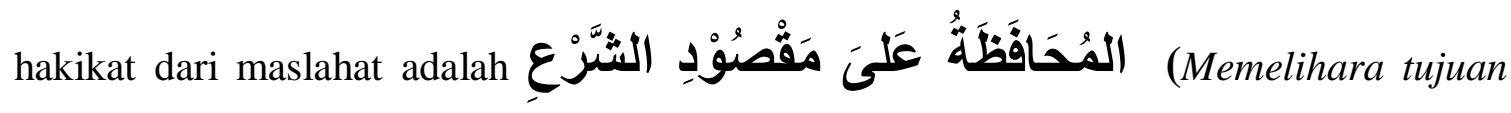
syara' (dalam menetapkan hukum)).

Sedangkan tujuan syara' dalam proses penentapan hukum atau lebih dikenal dengan maqashid syariah, ada lima, yaitu: memelihara agama, jiwa, akal, keturunan dan harta. Kemaslahatan menurut Imam Ghazali harus sejalan dengan hukum syara', meskipun harus atau akan bertentangan dengan kepentingan. Hal tersebut dikarenakan keterbatasan manusia dalam menjelaskan sebuah kemaslahatan pada sebuah pekerjaan,

\footnotetext{
${ }^{8}$ Wahbah al-Zuhaily, Ushul al-Fiqh al-Islamy, Juz 2, (Beirut, Dar al-Fikr, 2009), 818.

${ }^{9}$ Amir Syarifuddin, Ushul Fiqh, Jilid 2, (Jakarta: Kencana, 2009), 323-324.
} 
belum lagi terdapat pengaruh nafsu yang seringkali mendominasi pada pertimbangan akal manusia. ${ }^{10}$

Al-Qur'an dan Hadits sebagai sumber Hukum utama dalam Islam hanya berisi secara global pada seluruh aspek kehidupan. Al-Syahrastani mengatakan: "Teks-teks nash itu terbatas, pada sisi yang lain problematika hukum telah memerlukan solusi dengan cepat dan tepat, sehingga diperlukan upaya untuk menginterpretasi isi nash tersebut agar berbagai masalah yang tidak dikemukakan dalam nash dapat dicari pemecahannya. Oleh karena itu permasalahan baru yang muncul karena perkembangan zaman, tidak melulu dihadapkan dengan nash yang telah, akan tetapi juga harus dicari penyelesainnya secara ijtihadi dengan metode di dalamnya. Pandangan ini merupakan anjuran bahkan bias dikategorikan sebagai perintah kepada pakar hukum Islam dari setiap zamnnya, untu mengembangkan keilmuan di bidang istinbat al-ahkam.

Golongan Maliky sebagai pembawa bendera maslahat mursalah, mengemukakan alasan sebagai berikut: (1) sahabat telah mengggunakan maslahat mursalah pada masanya; (2) terdapat unsur maslahat yang sejalan dengan Maqasid as-Syari'ah (tujuantujuan syari'), sehingga dengan melaksanakan pekerjaan yang mengadung maslahat berarti sama dengan merealisasikan Maqasid as-Syari'ah. Sebaliknya mengesampingkan maslahat berarti mengesampingkan Maqasid as-Syari'ah. Sedang mengesampingkan Maqasid as-Syari'ah adalah batal. Oleh karena itu, boleh menggunakan dalil maslahat sebagai sumber hukum pokok ( $a s h l$ ) yang berdiri sendiri. Metode penemuan hukum ini tidak keluar dari sumber-sumber pokok hukum Islam, bahkan telah ada penyesuaian antara maslahat dan Maqasid as-Syari'; (3) menolak unsur kemaslahatan pada sebuah pekerjaan, sama saja akan membuat kesuliatan bagi orang Islam itu sendiri, hal ini sejalan dengan firman Allah:

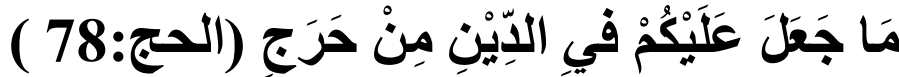

"Dan tidak sekali-kali menjadikan untuk kamu dalam agama suatu kesempitan" (QS al-Hajj"78)

Golongan Syafi'iyyah dan Hanafiyah sangat memperketat ketentuan maslahat. Maslahat harus mengacu kepada qiyas yang mempunyai 'illat yang jelas batasannya (mundhabithah). Karenanya, disitu harus terdapat ashl (sumber-sumber pokok) yang dijadikan maqis alaih (landasan qiyas). Dan 'illat harus jelas batasannya yang

\footnotetext{
${ }^{10}$ Dahlan Tamrin, Filasafat Hukum Islam, (Malang: UIN Malang Press, 2007), 96.
} 
mengandung esensi maslahat, meskipun kemaslahatan terkadang tidak mengandung 'illat dalam kondisi tertentu. ${ }^{11}$

Al-Ghazali sebagai pengikut Imam Syafi'i secara tegas dalam kitabnya almadkhal dan al-mushtasfa menyatakan bahwa ia menerima penggunaan maslahat mursalah dengan syarat bahwa maslahat itu dharuri (berhubungan dengan kebutuhan pokok kehidupan manusia), qath'i (pasti) dan kulli (menyeluruh), hal itu semua harus ada secara kumulatif. ${ }^{12}$

Abdul Wahhab Khalaf dalam kitab Ushul Fiqhnya menjelaskan beberapa persyaratan dalam mengaplikasikan maslahat mursalah, yaitu:

1. Perbuatan yang mengandung maslahat, harus sesuai dengan hakikat sebenarnya, yakni mendatangkan kemanfaat dan menolak kemudharatan. Serta tidak termasukd dalam dugaan belaka

2. Perbuatan yang mengandung maslahat tersebut, merupakan kepentingan orang banyak, bukan hanya beberapa individu saja.

3. Perbuatan yang mengandung maslahat tersebut, harus sejalan serta tidak boleh bertentangan dengan nash yang sudah qath'i

Sementara itu, al-Buthi berpendapat al- Maslahat dapat dijadikan sebagai sumber hukum jika memenuhi lima kriteria yang ia istilahkan dengan dlowabith almaslahat. Kelima kriteria tersebut ialah: maslahat tersebut haruslah (1) sejalan dengan maksud Maqhashid al-Syar'iyyah yang lima, (2) tidak bertentangan dengan al-Qur'an, (3) tidak bertentangan dengan hadits, (4) tidak bertentangan dengan Qiyas dan (5) tidak bertentangan dengan kemaslahatan lain yang lebih tinggi/ lebih kuat/lebih penting. ${ }^{13}$

\footnotetext{
${ }^{11}$ Ibid., 433.

12 Amir Syarifuddin, Ushul Fiqh, jilid 2, 336.

${ }^{13}$ Dahlan Tamrin, Filasafat Hukum Islam, 113.
} 


\section{Hibah dalam Kompilasi Hukum Islam}

Menurut istilah, hibah merupkan akad yang dilaksanakan oleh kedua belah pihak untuk pemindahan hak milik kepada orang lain pada waktu pemberi hibah masih hidup. Sedangkan konsep hibah dalam Kompilasi Hukum Islam (KHI) telah diatur pada Pasal 171g, "hibah adalah pemberian suatu benda secara sukarela dan tanpa imbalan dari seseorang kepada orang lain yang masih hidup untuk dimilikinya". ${ }^{14}$ Ada 3 syarat yang harus dipenuhi dalam melaksanakan hibah menurut Hukum Islam, yaitu:

1. Ijab, yaitu sebuah pernyataanm baik lisan maupun, yang pada isinya pemberian barang hibah dari.

2. Qabul, yaitu sebuah pernyataan dari yang menerima hibah tersebut.

3. Qadlah, yaitu penyerahan milik sendiri.

Seseorang yang hendak menghibahkan sebagian atau seluruh harta peninggalan semasa hidupnya, telah diatur dalam Kompilasi Hukum Islam (KHI) pasal 210 harus memenuhi syarat-syarat sebagai berikut: ${ }^{15}$

1. Orang tersebut telah berumur sekurang-kurangnya 21 tahun.

2. Harus berakal sehat.

3. Tidak adanya paksaan.

4. Menghibahkan sebanyak-banyaknya $1 / 3$ harta bendanya kepada orang lain atau lembaga.

5. Hibah diberikan di hadapan dua orang saksi.

Hibah menurut Kompilasi Hukum Islam memiliki tujuan untuk meningkatkan hubungan sosial yang lebih baik serta bisa untuk mengakrabkan hubungan sesama umat Islam. Agama Islam, sesuai dengan arti namanya tersebut, bertujuan agar pengikutnya hidup bersama secara damai, aman, serta penuh cinta kasih sayang, dan saling membantu dalam mengatasi masalah bersama atau pribadi. Untuk terciptanya hal tersebut, salah satu jalan yang dianjurkan Islam adalah hibah. ${ }^{16}$

Setiap orang pada dasarnya bleh melaksanakan hibah kepada individu siapa saja yang dia tuju, serta dilaksanakan ketika pemberi hibah masih dalam keadaan sehat. Pelaksanaan hibah dilakukan oleh pemberi hibah tanpa ada tambahan pertukaran barang

\footnotetext{
${ }^{14}$ Pasal 171 Ayat g Intruksi Presiden No. 1 tahun 1991 tentang Kompilasi Hukum Islam

${ }^{15}$ Simanjuntak, Pokok-pokok Hukum Perdata Indonesia (Jakarta: Djambatan, 1999), 295-296.

${ }^{16}$ Abdul Aziz Dahlan, Ensiklopedi Hukum Islam, Jilid 2, 540.
} 
apapun dari penerima hibah. Sehingga, pelaksaan hibah dilaksanakan secara bebas demi kepentingan individu atau kepentingan bersama. ${ }^{17}$

Dalam konteks hubungan keluarga, terdapat hubungan suami Istri hubungannya dengan hibah. Pada dasarnya sama-sama dibolehkan suami atau istri melaksanakan hibah, dengan tanpa terbatas siapa saja yang menjadi penerima hibahnya. ${ }^{18}$ Kompilasi Hukum Islam bab XIII pasal 86 disebutkan:

1. Pada dasarnya tidak ada percampuran antara harta suami dan istri karena perkawinan.

2. Harta istri tetap menjadi hak istri dan dikuasai penuh olehnya, demikian juga harta suami tetap menjadi hak suami dan dikuasai penuh olehnya.

Mengenai harta bawaan dalam perkawinan, Kompilasi Hukum Islam mengatur lebih lanjut dalam pasal 87 ayat 1, bahwa "harta bawaan dari masing-masing suami dan istri dan harta yang diperoleh dari masing-masing sebagai hadiah atau warisan adalah di bawah penguasaan masing-masing sepanjang para pihak tidak menentukan lain dalam perjanjian perkawinan". Guna melengkapi hal itu ayat selanjutnya menegaskan bahwa suami atau istri, masing-masing mempunyai hak sepenuhnya untuk melakukan perbuatan hukum atas harta masing-masing, baik berupa hibah, hadiah, sodaqah atau lainnya.

Dengan melihat beberapa pasal yang ada dalam Kompilasi Hukum Islam maupun dalil-dalil naqli, maka suami maupun istri berhak dan memiliki wewenang atas harta masing-masing. Sehingga, suami tidak berhak atas harta istrinya karena kekuasaan istri terhadap hartanya tetap dan tidak berkurang dikarenakan perkawinan. ${ }^{19}$ Karena itu suami istri berhak mempergunakan hartanya untuk dibelanjakan maupun dihibahkan, dan suami berhak untuk menghibahkan hartanya kepada istrinya maupun sebaliknya.

Faktor-faktor yang melatarbelakangi hal tersebut antara lain adalah:

1. Harta istri tetap menjadi hak milik istri dan dikuasai penuh olehnya, demikian juga harta suami tetap menjadi hak suami dan dikuasai penuh olehnya. Suami tidak berhak atas harta istrinya karena kekuasaan istri terhadap hartanya tetap dan tidak berkurang disebabkan perkawinan.

\footnotetext{
${ }^{17}$ Sudarsono, Hukum Waris dan Sistem Bilateral (Jakarta: Rineka Cipta, 1991), 103.

18 Ibid., 104.

${ }^{19}$ Idris Ramulyo, Hukum Perkawinan, Hukum Kewarisan, Hukum Acara Peradilan Agama dan Zakat menurut Hukum Islam (Jakarta: Sinar Grafika, 2006), 30.
} 
2. Hibah menjadi sah apabila telah memenuhi beberapa syarat, demikian pula hibah antara suami-istri tetap dibolehkan.

3. Barang hibah merupakan barang halal, serta setelah hibah itu terjadi tidak akan dikhawatirkan terjadi mafsadat yang besar.

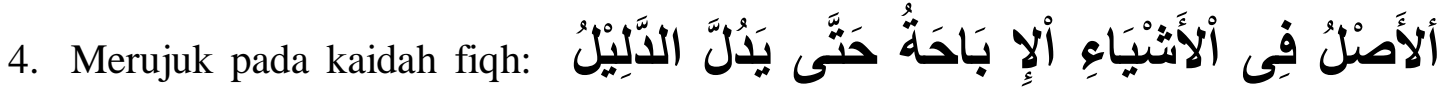
(Segala sesuatu pada dasarnya boleh, sampai ada dalil yang mengharamkannya)

\section{KUHPerdata berbicara Hibah}

Hibah dalam KUHPerdata telah diatur pada Pasal 1666, penghibahan (bahasa Belanda: schenking, bahasa Inggris: danation) diartikan sebagai:

Hibah adalah suatu perjanjian dengan mana si penghibah, diwaktu hidupnya, dengan cuma-cuma dan dengan tidak dapat ditarik kembali, menyerahkan suatu benda guna keperluan si penerima hibah yang menerima penyerahan itu.

Undang-undang tidak mengakui lain-lain hibah selain hibah-hibah diantara orang-orang yang masih hidup. ${ }^{20}$

Praktek hibah ini digolongkan pada praktek perjanjian "dengan cuma-cuma" (bahasa Belanda: "om niet"), tulisan "dengan cuma-cuma" pada pasal 1666 tersebut, ditujukan hanya pada nampaknya prestasi dari satu pihak saja, sedang pihak yang lainnya tanpa memberikan kontra-prestasi sebagai balasan dari prestasi tersebut. Perjanjian yang demikian itu diistilahkan juga perjanjian sepihak (unilateral) sebagai lawan dari perjanjian timbal balik (bilateral). ${ }^{21}$

Tulisan "diwaktu hidupnya" pemberi hibah pada pasal 1666, merupakan suatu cara untuk membedakan praktek hibah dengan pemberian lainnya yang dilakukan dalam suatu surat wasiat (testament). Pada praktek yang lain, hibah akan telaksana setelah pemberi hibah meninggat, maka hibah tersebut telah mempunya kekuatan hukum tetap, dapat dirubah atau ditarik kembali olehnya. Pemberian tersebut dala KUHPerdata dikenal dengan "legaat" (hibah wasiat) yang diatur dalam peraturan hukum waris, sedangkan praktek hibah merupakan suatu perjanjian. Karena penghibahan menurut

${ }^{20}$ R. Subekti dan R. Tjitrosudibio, Kitab Undang-undang Hukum Perdata (Jakarta: Balai Pustaka, 2009), 436.

${ }^{21}$ Subekti, Aneka Perjanjian (Bandung: PT. Citra Aditya Bakti, 1995), 95. 
KUHPerdata itu adalah suatu perjanjian, maka sudah dengan sendirinya ia tidak boleh ditarik kembali secara sepihak oleh pemberi hibah.

KUHPerdata secara tegas tidak menyebutkan tentang syarat-syarat hibah. Akan tetapi, melihat kembali pasal 1666 KUH Perdata, dapat dirumuskan tentang syarat-syarat hibah versi KUHPerdata, diantaranya adalah: 1) Adanya Perjanjian; 2) Penghibah; 3) Penerima Hibah; dan 4) Barang Hibah.

Pada hukum perdata, ada beberapa praktek yang mirip dengan praktek hibab, yakni schenking (bahasa Belanda) dan gift (bahasa Inggris). Akan tetapi antara schenking dengan hibah sangat berbeda pada prakteknya, terutama yang berkaitan dengan harta yang menjadi kewenangan istri dalam hubungan keluarga. Demikian juga yang terjadi antara suami-istri schenking tidak dapat dilaksanakan oleh istei tanpa bantuan suami. Hal tersebut sama dengan praktek schenking, yakni tidak boleh antara suami-istri. ${ }^{22}$

Wanita yang telah memiliki suami menurut Hukum Barat (KUHPerdata) pada pasal 119 BW menyebutkan:

"Mulai saat perkawinan dilangsungkan, demi hukum berlakulah persatuan bulat antara harta kekayaan suami dan istri, sekedar mengenai itu dengan perjanjian kawin tidak diadakan ketentuan lain.

Persatuan itu sepanjang perkawinan tak boleh ditiadakan atau diubah dengan sesuatu persetujuan antara suami dan istri".

Jadi hukum perkawinan dalam KUH Perdata menganut azas persatuan atau pencampuran harta kekayaan atau asas harta kekayaan bersama. Akan tetapi, suami istri dapat melakukan penyimpangan terhadap aturan yang telah tercantum pada KUHPerdata, namun dengan harus melalui akta tertulis dihadapan notaris tersumpah. Pada dasarnya, harta kekayaan di dalam perkawinan itu tidak boleh diadakan perubahan apapun juga selama perkawinan. Hal demikian dimaksudkan untuk melindungi pihak ketiga. Bahkan selama perkawinan jual beli atau hibah antara suami istri pun dilarang. ${ }^{23}$ Sebagaimana pasal 1678 disebutkan bahwa:

"Dilarang adalah penghibahan antara suami-istri selama perkawinan. Namun ketentuan ini tidak berlaku terhadap hadiah-hadiah atau pemberian-pemberian benda-benda bergerak yang bertubuh, yang harganya tidak terlalu tinggi mengingat kemampuan si penghibah."

\footnotetext{
${ }^{22}$ Sudarsono, Hukum Waris dan Sistem Bilateral, 104.

${ }^{23}$ Komariah, Hukum Perdata (Malang: UPT Penerbitan Universitas Muhammadiyah Malang, 2013 ), 54.
} 
Pasal 1678 KUHPerdata tersebut melarang praktek hibah antara suami dan istri selama ada hubungan perkawinan. Ketentuan dalam pasal 1678 tersebut, tidak berlaku terhadap hadiah ataupun pemberian benda bergerak yang bertubuh, yang harga barangnya tidak terlalu tinggi terhadap kemampuan pemberi hibah. Ketentuan tersebut hanya memiliki arti jika terjadi perkawinan antara laki-laki dan perempuan, dengan perjanjian perpisahan kekayaan, sebab kalau mereka itu melaksanakan perkawinan dalam percampuran harta kekayaan, maka kekayaan kedua belah pihak menjadi satu, yakni harta campuran, baik kekayaan yang dibawanya ke dalam perkawinan maupun kekayaan yang diperoleh masing-masing selama perkawinan. Ketentuan ini dimaksudkan untuk melindungi pihak ketiga yang mengadakan transaksi dengan suami atau istri dimana mereka menyandarkan kepercayaan mereka kepada kekayaan suami atau istri itu. ${ }^{24}$

Faktor-faktor yang melatarbelakangi larangan hibah antara suami-istri dalam KUH Perdata, antara lain adalah:

1. Larangan tersebut didasarkan atas pertimbangan demi menghindarkan peralihan harta benda suami ke dalam harta benda istri atau sebaliknya.

2. Alasan larangan pemberian antara suami istri ini juga terletak pada keinginan pembentuk undang-undang akan menghindarkan penipuan dan korupsi perihal pemindahan hak milik dari suami kepada istri atau sebaliknya.

3. Larangan penghibahan suami-istri tersebut tidak ada artinya apabila suamiistri kawin tanpa perjanjian perkawinan.

4. Untuk memperlindungi pihak ketiga yang mempunyai tagihan kepada salah seorang di antara suami-istri tersebut.

\section{Unsur Kemaslahatan hibah antara Suami - Istri}

Kemaslahatan umat banyak ditentukan oleh faktor waktu, tempat, dan keadaan. Sehingga, kemaslahatan dapat berubah apabila waktu berubah dan kondisi masyarakat juga sudah mengalami perubahan. Apa yang dianggap maslahat pada waktu tertentu, dalam waktu berikutnya mungkin tidak bisa dianggap maslahat lagi, begitu pula sebaliknya. Apabila pemikiran tentang hukum banyak ditentukan oleh situasi dan kondisi, maka pemikiran itu berkembang bila situasi dan kondisi sudah berubah.

Dalam Kompilasi Hukum Islam (KHI) pasal 87 dinyatakan, bahwa:

\footnotetext{
${ }^{24}$ Subekti, Aneka Perjanjian, 100.
} 
"Harta bawaan dari masing-masing suami dan istri dan harta yang diperoleh masing-masing sebagai hadiah atau warisan adalah di bawah penguasaan masing-masing, sepanjang para pihak tidak menentukan lain dalam perjajian perkawinan.

Suami dan istri mempunyai hak sepenuhnya untuk melakukan perbuatan hukum atas harta masing-masing berupa hibah, hadiah, sodaqah, atau lainnya."

Ketentuan yang terdapat dalam Kompilasi Hukum Islam tersebut tampaknya tidak sejalan atau berbeda dengan ketentuan yang ada dalam KUH Perdata pasal 1678 yang berbunyi:

"Dilarang adalah penghibahan antara suami-istri selama perkawinan.

Namun ketentuan ini tidak berlaku terhadap hadiah-hadiah atau pemberianpemberian benda-benda bergerak yang bertubuh, yang harganya tidak terlalu tinggi mengingat kemampuan si penghibah."

Sehingga agar baik hakim maupun masyarakat tidak mengalami kebingungan dalam menilai aturan hukum mana yang lebih baik dan bermanfaat, maka disini diperlukan sebuah teori yang dapat dijadikan pijakan. Dalam hal ini penulis menggunakan teori kemaslahatan untuk menilai kedua aturan hukum tersebut. Untuk lebih memudahkan menganalisis maka disini teori kemaslahatan tersebut akan ditinjau dari beberapa segi.

Perbedaan aturan hukum di samping memberikan dampak yang positif, juga dapat memberikan dampak yang negatif terhadap eksistensi rumah tangga. Bahkan dapat menimbulkan keretakan dalam rumah tangga dan dapat merusak nilai-nilai agama. Maksud dari kekeluargaan adalah kerukunan antara keluarga atau suasana damai, saling kasih-mengasihi, cinta-mencintai serta tolong-menolong yang di dambakan. Teori kemaslahatan dari segi kekeluargaan ini dapat diartikan sebagai sesuatu yang mendatangkan kemanfaatan dan menghindarkan kerusakan bagi kerukunan antar anggota keluarga.

Perbuatan hukum yang baik antara suami-istri dapat menjadikan contoh kepada anggota keluarga yang lain dalam membentuk keluarga yang bahagia. Kebahagiaan suami-istri dalam perkawinan itu dapat dirasakan dan dihayati oleh masing-masing suami-istri. Dan kebahagiaan yang dapat dirasakan dan dihayati oleh suami dan istri merupakan kriteria untuk menilai suatu perkawinan yang berhasil. ${ }^{25}$

Salah satu perbuatan hukum yang dapat di lakukan oleh suami maupun istri adalah hibah. Akan tetapi, hibah antara suami-istri yang mempunyai maksud dan tujuan

\footnotetext{
${ }^{25}$ Jalaluddin Rahmat dan Muhtar Gandaatmaja, Keluarga Muslim dalam Masyarakat Modern (Bandung: PT. Remaja Rosdakarya, 1993), 16.
} 
yang baik yaitu agar lebih saling mencintai dan saling menyayangi itu belum tentu menimbulkan akibat yang baik pula.

Di dalam Kompilasi Hukum Islam, suami dapat menghibahkan hartanya kepada istri dan begitu pula sebaliknya istri dapat menghibahkan hartanya kepada suami. Pernyataan Kompilasi Hukum Islam pasal 87 tentang: "Harta bawaan dari masingmasing suami dan istri dan harta yang diperoleh masing-masing sebagai hadiah atau warisan adalah di bawah penguasaan masing-masing, sepanjang para pihak tidak menentukan lain dalam perjajian perkawinan. Suami dan istri mempunyai hak sepenuhnya untuk melakukan perbuatan hukum atas harta masing-masing berupa hibah, hadiah, sodaqah, atau lainnya", jika di tinjau menurut teori kemaslahatan dari segi kekeluargaan, khususnya untuk menciptakan keluarga yang bahagia antara suami-istri maka hal tersebut dapat di terima (boleh). Apalagi dengan melihat maksud dan tujuan yang baik dari suami-istri itu sendiri.

Suami ataupun istri dapat memberikan harta untuk dihibahkan jika harta yang dihibahkan tersebut terpisah dari yang lainnya dan tidak terkait dengan harta atau hak lainnya. Karena prinsip barang yang dihibahkan itu dapat dipergunakan oleh penerima hibah setelah akad dinyatakan sah. ${ }^{26}$

Hibah menurut Pasal $171 \mathrm{KHI}$ adalah pemberian suatu benda secara sukarela dan tanpa imbalan dari seseorang kepada orang lain yang masih hidup untuk dimiliki. Dalam hal ini tidak ada ketentuan tentang siapa pihak yang akan atau berhak menerima hibah, baik kepada ahli waris (anak, istri atau suami), sahabat karib, dan sebagainya. Sehingga hibah dapat di berikan kepada siapa saja.

Kebolehan hibah antara suami-istri ini didukung oleh surah Al Baqarah ayat 177 yang berbunyi:

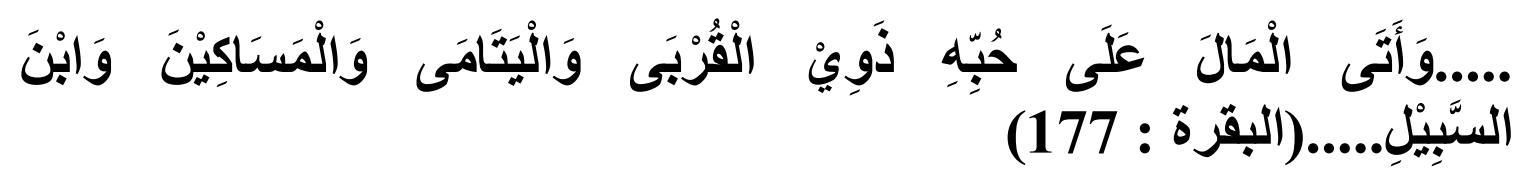

"...Dan memberikan harta yang dicintainya kepada kerabatnya, anak-anak yatim, orang-orang miskin, musafir (yang memerlukan pertolongan)...."(Q.S Al Baqarah: 177)

Ayat tersebut merupakan salah satu rujukan dasar hukum KHI mengenai hibah yang tidak bertentangan dengan teori kemaslahatan dari sisi kekeluargaan. Selain ayat di

\footnotetext{
${ }^{26}$ Abdul Aziz Dahlan, Ensiklopedi Hukum Islam, Jilid 2, 541.
} 
atas kebolehan hibah antara suami-istri tersebut yang menjamin kemaslahatan didukung pula oleh kaidah fiqh:

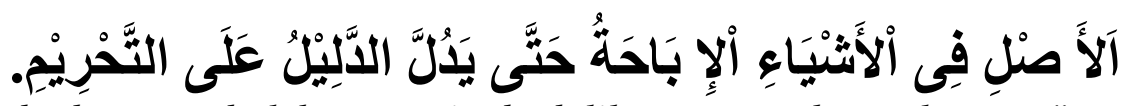

"Segala sesuatu pada dasarnya boleh, sampai ada dalil yang mengharamkannya."

Karena teori kemaslahatan disini lebih menekankan kepada unsur kemaslahatan atau kemanfaatan manusia itu sendiri. Sehingga, apabila hibah yang dilakukan antara suami-istri itu dapat mewujudkan keluarga yang bahagia, serta dapat memperbaiki hubungan suami-istri dan lebih menumbuhkan rasa saling mencintai antar suami-istri maka hal tersebut dapat diterima dan dibenarkan.

Berbeda dengan Kompilasi Hukum Islam, KUH Perdata tampaknya lebih rinci dalam mengatur masalah hibah. Ada hal yang menarik jika di analisis lebih lanjut bunyi pasal 1678 KUH Perdata yang menyebutkan:

"Dilarang adalah penghibahan antara suami-istri selama perkawinan.

Namun ketentuan ini tidak berlaku terhadap hadiah-hadiah atau pemberianpemberian benda-benda bergerak yang bertubuh, yang harganya tidak terlalu tinggi mengingat kemampuan si penghibah."

Persoalannya adalah larangan hibah antara suami-istri selama perkawinan. Menurut hemat penulis, pernyataan larangan hibah antara suami-istri tersebut jika di tinjau dari teori kemaslahatan segi kekeluargaan maka hal tersebut kurang menjamin kemaslahatan bagi keluarga itu sendiri. Karena di samping larangan tersebut bertentangan dengan nash maupun kaidah fiqh, larangan tersebut juga dapat memicu timbulnya keretakan maupun percekcokan antara keluarga maupun suami-istri itu sendiri dan dapat memutuskan tali persaudaraan di antara mereka. Seorang suami tidak boleh menarik kembali pemberian yang diberikan kepada istrinya atau sebaliknya. Karena jika pemberian tersebut diminta kembali, maka akan dapat menimbulkan permusuhan di antara mereka. Sehingga, kehidupan rumah tangga yang sakinah, mawaddah, warahmah menjadi tidak terwujud.

Sehingga untuk mengantisipasi kemungkinan-kemungkinan tersebut, para suami ataupun istri menghibahkan harta kekayaannya dengan di porsikan sebagaimana hak-hak (suami/istri) dan ahli waris lainnya waktu menerima warisan. Hibah dengan sistem waris jika dilihat dari Hukum Islam adalah boleh, karena hal tersebut dilakukan demi kemaslahatan dan kesejahteraan keluarga. Dan diharapkan nantinya sepeninggal penghibah, mereka tidak sulit untuk membagi harta warisan itu karena sudah di bagi sebelumnya. 
Kemaslahatan dan kemafsadatan di dunia dan di akhirat serta sebab-sebab keduanya tidak dapat diketahui kecuali melalui syari'at. Adapun kemaslahatan dan kemafsadatan di dunia serta sebab-sebabnya dapat diketahui melalui keperluankeperluan, kebiasaan-kebiasaan, serta dugaan-dugaan yang kuat. Izzudin Ibnu Abdissalam mengatakan, kebanyakan maslahat dan mafsadat keduniaan dapat di ketahui melalui akal dan itu merupakan bagian terbesar dari syari'at. Sa'id Ramadhan Al Buthi, seorang ahli teori hukum mazhab hanbal mengatakan, bahwa akal dapat menentukan kemaslahatan dan kemafsadatan khususnya dalam lapangan mu'amalah.

Dengan berpegang pada pedoman individual rights (hak dan kebebasan pribadi) maupun property rights (hak untuk memiliki kekayaan) dalam syari'ah Islam, maka jelaslah kiranya bahwa menjadi kaya, atau berupaya untuk memupuk kekayaan, bukan sesuatu yang diharamkan dalam Islam. Kemiskinan justru merupakan musuh terbesar umat manusia. Menurut pandangan Islam, untuk memerangi kemiskinan tersebut merupakan kewajiban umat yang mampu dan kaya, untuk mengurangi penderitaan mereka yang miskin tersebut dengan cara membayar zakat yang wajib, maupun yang sunah, seperti infak, sedekah, maupun hibah. ${ }^{27}$

Terkait dengan teori kemaslahatan maka kegiatan-kegiatan yang sah dan yang sepenuhnya sejalan dengan kebajikan sosial yang dapat dibenarkan. Sedangkan, kegiatan-kegiatan yang tidak meningkatkan kesejahteraan manusia tidak dibenarkan. Konsep persaudaraan dan perlakuan yang sama bagi setiap individu dalam masyarakat dan dihadapan hukum, harus diimbangi dengan keadilan ekonomi. Tanpa pengimbangan tersebut keadilan sosial kehilangan makna. Dengan keadilan ekonomi, setiap individu akan mendapatkan haknya sesuai dengan kontribusi masing-masing kepada masyarakat. Setiap individupun harus terbebaskan dari eksploitasi individu lainnya. Islam dengan tegas melarang seorang muslim merugikan orang lain.

Pada dasarnya setiap barang yang boleh di jual, boleh juga dihibahkan. Hibah tidak boleh di tarik kembali, meskipun hibah itu pemberian suami kepada istrinya. ${ }^{28}$ Seseorang tidak di haramkan untuk menjadi kaya atau berupaya untuk menjadi kaya. Sehingga seseorang boleh menerima hibah. Kedudukan ekonomi dalam keluarga, menggambarkan bahwa kehidupan keluarga harus dapat mengatur diri dalam

\footnotetext{
${ }^{27}$ Jalaluddin Rahmat dan Muhtar Gandaatmaja, Keluarga Muslim dalam Masyarakat Modern, 43-44.

${ }^{28}$ Bahder Johan Nasution dan Sri Wijayati, Hukum Perdata Islam Kompetensi Peradilan Agama tentang Perkawinan, Waris, Wasiat, Hibah, Wakaf dan Shodaqah (Bandung: Mandar Maju, 1997), 62.
} 
mempergunakan sumber-sumber keluarga dalam memenuhi kebutuhan-kebutuhan keluarga dengan cara yang cukup efektif dan efisien. Cara yang efektif dan efisien ini dapat di laksanakan dengan baik dalam kehidupan keluarga apabila adanya kerja sama di antara anggota keluarga. ${ }^{29}$

Kebolehan hibah antara suami-istri dalam pasal 87 Kompilasi Hukum Islam, dapat membawa kemaslahatan dari segi kekeluargaan, namun kebolehan tersebut belum tentu memabawa kemaslahatan dari segi ekonomi Islam.

Menurut hemat penulis, menyangkut larangan hibah antara suami-istri dalam KUH Perdata dengan alasan: didasarkan atas pertimbangan demi menghindarkan peralihan harta benda suami ke dalam harta benda istri atau sebaliknya, larangan pemberian antara suami istri ini juga terletak pada keinginan pembentuk undang-undang akan menghindarkan penipuan dan korupsi perihal pemindahan hak milik dari suami kepada istri atau sebaliknya, dan sebagainya lebih menjamin kemaslahatan bagi masyarakat. Karena, dengan adanya larangan hibah tersebut, seseorang yang mengadakan perjanjian dengan salah satu suami maupun istri tidak akan dirugikan.

Suami tidak dapat memindahkan hak milik atas barang-barang yang berharga kepada istrinya apabila akan disita atau dilelang oleh Pengadilan untuk pembayaran hutang kepada krediturnya. Sehingga disini orang yang mengadakan perjanjian dengan si suami maupun si istri tidak perlu khawatir akan perjanjian yang telah dibuatnya.

Berbeda dengan KUH Perdata yang melarang hibah antara suami-istri karena lebih melihat dampak yang akan terjadi apabila tidak adanya larangan, ketentuan Kompilasi Hukum Islam yang sudah jelas, dikarenakan sudah memiliki sandaran nash, Kompilasi Hukum Islam tidak berani keluar dari aturan tersebut. Ketentuan yang ada dalam KHI maupun KUH Perdata, kedua-duanya sama-sama mempunyai alasan dalam menetapkan hukum. Rujukan KHI dalam menetapkan hukum salah satunya adalah Hukum Islam. Sumber utama Hukum Islam adalah Al-Qur'an dan Al-Hadis. Al-Qur'an dan Hadis hanya menjelaskan segala aspek kehidupan secara garis besar atau global saja apalagi dalam masalah muamalah.

Sehingga menurut penulis, selama dengan adanya larangan hibah yang di pandang baik oleh akal sehat karena mendatangkan kebaikan dan menghindarkan keburukan bagi manusia, khususnya untuk melindungi pihak-pihak yang mengadakan

\footnotetext{
${ }^{29}$ Jalaluddin Rahmat dan Muhtar Gandaatmaja, Keluarga Muslim dalam Masyarakat Modern, 9.
} 
perjanjian dengan si suami maupun si istri, maka hal tersebut dapat dipandang lebih mencerminkan kemaslahatan dalam segi sosial. Larangan hibah antara suami-istri, merupakan larangan yang dapat mendatangkan kebaikan bagi orang lain, sehingga larangan tersebut merupakan kemaslahatan. Larangan tersebut juga dianggap maslahat dikarenakan berupa kepentingan umum.

\section{Kesimpulan}

Perbedaan aturan hukum di samping memberikan dampak yang positif, juga dapat memberikan dampak yang negatif terhadap eksistensi rumah tangga. Bahkan dapat menimbulkan keretakan dalam rumah tangga dan dapat merusak nilai-nilai agama. Maksud dari kekeluargaan adalah kerukunan antara keluarga atau suasana damai, saling kasih-mengasihi, cinta-mencintai serta tolong-menolong yang di dambakan. Teori kemaslahatan dari segi kekeluargaan ini dapat diartikan sebagai sesuatu yang mendatangkan kemanfaatan dan menghindarkan kerusakan bagi kerukunan antar anggota keluarga.

Perbuatan hukum yang baik antara suami-istri dapat menjadikan contoh kepada anggota keluarga yang lain dalam membentuk keluarga yang bahagia. Kebahagiaan suami-istri dalam perkawinan itu dapat dirasakan dan dihayati oleh masing-masing suami-istri. Dan kebahagiaan yang dapat dirasakan dan dihayati oleh suami dan istri merupakan kriteria untuk menilai suatu perkawinan yang berhasil.

Kebolehan hibah antara suami-istri dalam pasal 87 Kompilasi Hukum Islam, dapat membawa kemaslahatan dari segi kekeluargaan, namun kebolehan tersebut belum tentu memabawa kemaslahatan dari segi ekonomi Islam.

Menurut hemat penulis, menyangkut larangan hibah antara suami-istri dalam KUH Perdata dengan alasan: didasarkan atas pertimbangan demi menghindarkan peralihan harta benda suami ke dalam harta benda istri atau sebaliknya, larangan pemberian antara suami istri ini juga terletak pada keinginan pembentuk undang-undang akan menghindarkan penipuan dan korupsi perihal pemindahan hak milik dari suami kepada istri atau sebaliknya, dan sebagainya lebih menjamin kemaslahatan bagi masyarakat. Karena, dengan adanya larangan hibah tersebut, seseorang yang mengadakan perjanjian dengan salah satu suami maupun istri tidak akan dirugikan. 


\section{DAFTAR PUSTAKA}

Abdul Aziz Dahlan, Ensiklopedi Hukum Islam, Jakarta: PT. Ichtiar Baru Van Hoeve, 1996

Abdul Djamali, Hukum Islam Berdasarkan Ketentuan Kurikulum Konsorsium Ilmu Hukum, Bandung: Mandar Maju, 2002

Afdol, Penerapan Hukum Waris Islam secara Adil, Surabaya: Airlangga University Press, 2013

Amir Syarifuddin, Ushul Fiqh, Jakarta: Kencana, 2009

Bahder Johan Nasution dan Sri Wijayati, Hukum Perdata Islam Kompetensi Peradilan Agama tentang Perkawinan, Waris, Wasiat, Hibah, Wakaf dan Shodaqah, Bandung: Mandar Maju, 1997

Dahlan Tamrin, Filasafat Hukum Islam, Malang: UIN Malang Press, 2007

Dirjen Pembinaan Kelembagaan Agama Islam, Ilmu Fiqh, Jakarta: Kementerian Agama RI, 1984

Idris Ramulyo, Hukum Perkawinan, Hukum Kewarisan, Hukum Acara Peradilan Agama dan Zakat menurut Hukum Islam, Jakarta: Sinar Grafika, 2006

Jalaluddin Rahmat dan Muhtar Gandaatmaja, Keluarga Muslim dalam Masyarakat Modern, Bandung: PT. Remaja Rosdakarya, 1993

Komariah, Hukum Perdata, Malang: UPT Penerbitan Universitas Muhammadiyah Malang, 2013

Mahmud Yunus, Hukum Perkawinan Dalam Islam, Jakarta: PT. Hidakarya Agung, 1996

R. Subekti dan R. Tjitrosudibio, Kitab Undang-undang Hukum Perdata, Jakarta: Balai Pustaka, 2009

Simanjuntak, Pokok-pokok Hukum Perdata Indonesia, Jakarta: Djambatan, 1999

Subekti, Aneka Perjanjian, Bandung: PT. Citra Aditya Bakti, 1995

Sudarsono, Hukum Waris dan Sistem Bilateral, Jakarta: Rineka Cipta, 1991

Wahbah al-Zuhaily, Ushul al-Fiqh al-Islamy, Beirut, Dar al-Fikr, 2009 